151 proof:

JNMO074Q

Joumal of Nuclear Materals $128 \& 129$ (1984) NNMCO7aO

North-Hulland. Amsierdam

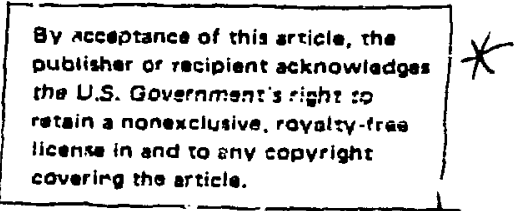

\title{
STUDIES ON IMPURITY CONTROL AND HYDROGEN PUMPING, WITH CHROMIUM GETTERING IN ISX-B *
}

\author{
P. MIODUSZEW'SKI. J.E. SIMPKINS. P.H. EDMONDS. R.C. ISLER. E.A. LA.ZA.RUS. C.H. MA. \\ M. MURAKAMI and A.J. WOUTTON
}

Fusion Enetg. Division Oak Ridge Natıanal Laburator Oah Ridge. Tennessee 37831. US.4

Key words: impurity conirol, chromum gettering. hydrogen pumping

$D=35001896$

\section{Introduction}

Gettering inside the vituum vessel has been employed in many tokamaks [1-j] and has led to strongly reduced inpunity radiation and expansion of the operating space. Except for one brief test with chromium [4]. titanium has been used until now as getter máterial. mostly because sources for large-scale applications are commerrially available. One of the characteristics of titanium is that it pumps large amounis of hydrogen by bulk diffusion even ai room temperature. As a consequence, titanium gettering requires increased gas flou rates and entails large hydrogen inventories. In contrast. chromium pumps hydrogen only is monolayer quantities on the surface without subsequent bulk diffusion. Therefore. chromium getienng allows the control of impurities without increased gas flow rates or hydrogen retention at the wall. This has the added advantage of minimizing the tritium inventory in DT-buming fusion devices.

\section{Physics data base and gettering technique}

A comparison of the gettering characteristics of chromiur and titanium bas been reported in a previous paper [5]. It was found that pumping of impurity gases like oxygen and ritrogen is very similar for Litanium and chromium. Hydrogen pumping on the other hand. is different for these two getter materials: chromium pumps hydrogen isotopes by surface adsorption only. whereas titanium absorbs large amounts of hydrogen by

- Research sponsored by the Office of Fusion Energ: UIS Department of Energy. under Coniraci No DE-ACOS84OR.'1400 with Marin Marietla Energ. Svsien.s. Ine. surface aitangption followed by bulk diffusion

To cover many square meters of surface area with the getter material. large scale chromium sublimation sources have been developed which are similar to the widely used VARIAN Ti-Balls ${ }^{\mathrm{TM}}$ [6]. Since the vapor pressure of chromium is higher than that of titanium at a given temperature. chromium gettering requires lower temperatures for given sublimation rates.

\section{Gettering proctedure}

To test chromium gettering in ISX. two getter source, separated toroidally about $180^{\circ}$, were installed in the 10rus. The sublimation rate was chosen to be $0.1 \mathrm{~g} / \mathrm{h}$ for each source. A typical getter cycle lasied for $30 \mathrm{~min}$. This procedure was identic al to the usual titanium getter cycle in ISX to faciliate comparison between chromium

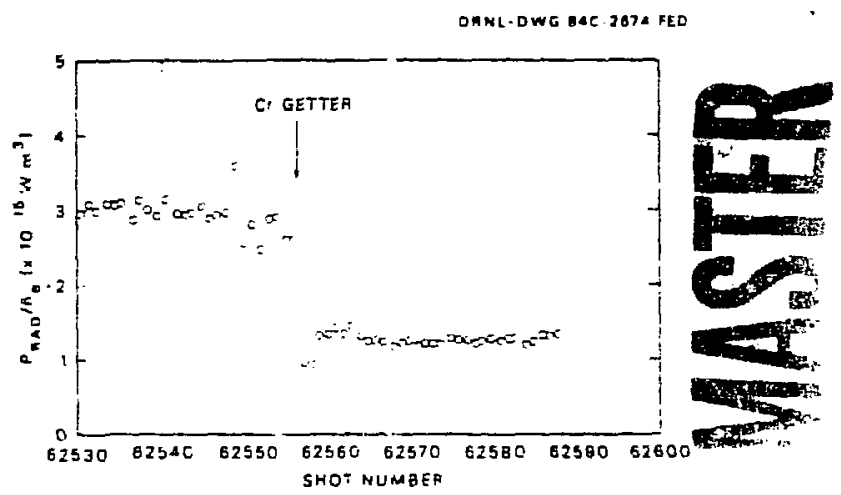

Fig. 1. Tolal radiated power from the plasma normalized to line-average density as a function of hor number before and after chromium gettering.

* 0022-3115/84/\$03.G0 (c Elsevier Science Publishers B.V. (North-Holland Phvsics Publishing Division)

\section{REOUEST}

Author. please indicale

- prinier's etrors in BLUE

- author's changes in RED

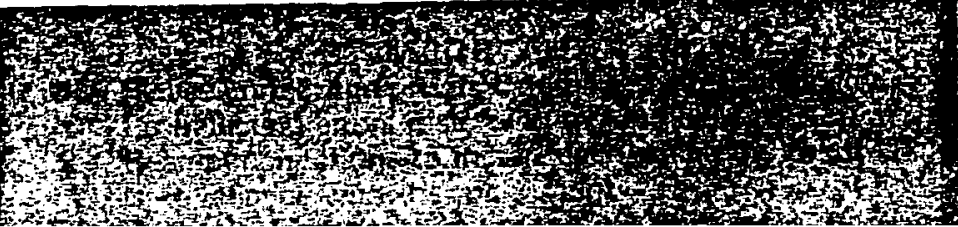


and rianium. Th: gettered area in the torus is estimated to be 705 with a film thickness of 1-j0 monolayers and about 5 sith a coverage of 10-100 monolayer.. From an oper-ionai viewpoint. chror ium gettring was very convenient. While titasuus sources have to be outrassed and conditionej, sometiries ior several hours. outgassing of the chromium ball. wa negligible. After only $5 \mathrm{~min}$ into the getter cycle ill impuriy gases $\left(\mathrm{H}_{2} \mathrm{O}\right.$. $\mathrm{N}_{2}$. CO erc.) in the residual gas were reducet by facurs oi 3-5. And after a full getuer cycie of $30 \mathrm{~min}$ all impurites were doom by almost an order of :naqnitude.

\section{Impurity control}

After ehromium gettering the totai sadiatiun from the plasma was strongly reduced. The content of individual imfurities - as measured spaciroscopically was reduced by factors of 3-5. Fig. 1 shows the lotal radialed power from the plasma, normalized to the lin:-average density, before and after chromium gettering. In arflition to reciucuon of lotal radiated power from the plasma. the disibarges display high reproducibility after geusting. 1.t normalized radiaied power was monitored for up to 50 ischarges after the getter cycle and no exhaustion'n the impurity purnping capability wis obsirved

\section{Hydrogen numpiog}

Titanium gettering entails large pumping speeds an.? capacivies for hydrogen species. To votain reproducible discharge: withoul tedious adjustments of tie gas puft

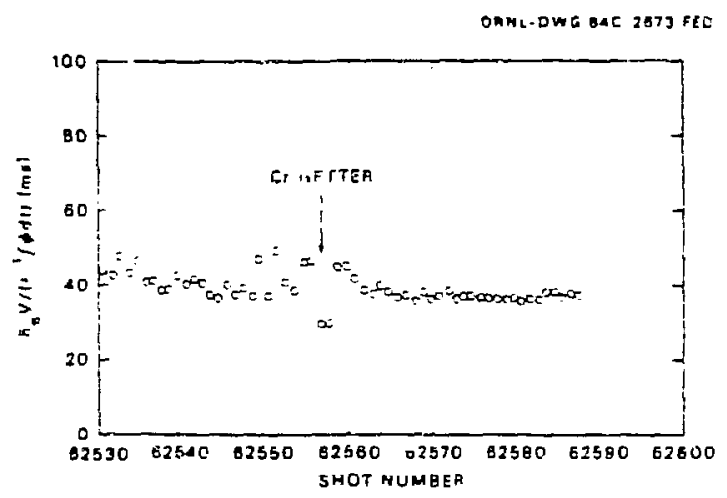

Fig. 2. Line-aver aged density normalized to gas now ( $\phi$ is the gas flow rate) as a function of shor number before and after chromium gettering. tetween shots, a procedure his been est blished in ISX that is referred to.as "ungetten " $g$ ". It involves puil.jg a large amount of hydrogen into the torus to saturate the kitanium. thus reducing the hydrogen pumping speed to a tolerably small valu. This pra edure d xes net affect the impurity punping capability, tecaus bydrogen on the geter surface is conumually replaced by the more reactive gases like cxyfer. Ir contras: 10 this buthaviour, curomium gevering dots no: sifnicinty chan: the pumping speed or capacio of the walls for hydrogsn isotopes. To cemonstrate thes, $f_{1}$. 2 show's the lise-ever. ace gas flow rate as itncior of shot number befors and aing gettering It uppears tha: the trquire fas now rate ior a given densiry is affecied for a 2 shots afie the getter cy 'e. as: 1 in subsequent discirarges ins elrs: hecomes neglugibie. 'Thi same effect is obstrved if iwe merely interrupt .uxari ak cocraition tor about $37 \mathrm{~m}$ ' $\mathrm{n}$ is assumes. thrsefore, th at increas fas flow mis is recessary to establish an equilibrium wall loading Comparing individual shots before and after chromium-geftering, the same line-average dea ity is obtained for a given gas hlow ratc. After titanium geitaring. on the other hand, gas flow rates have to be increased by facters of 2-3 to mainiain a given density.

\section{Operating space}

Finally. it is worth mention $7 g$ that the operating space has been increased - ignificartly after chromium getiering. A maximum line-ayerage deasity of $1.0 \times 10^{14}$ $\mathrm{cm}^{-3}$ has been achieved. This is the highesi dersiry observed in ISK. It coriesponds is a Murakami parameter of 11 a : $q_{4}=\ldots$. Thus, the sxpansion of $t w$. Operatin - space after chromiurn getrering is similar to that after titanium gettering without the disadvantage of increased gas now.

\section{Conclusions}

Chromium getteing has been proven to be a wouble-free and efficient miehod of surface pui jing in sokamaks. The impurity control capabilities are excellent and comparabie to that of itanium. The hydrogen uptake is reduced to monolayer quantives on the surface. The expansion of the operating space is similar to that seen with utanium without the disadvantage of surongy increased hydrogen fluxes. Possible applications of chromium gettering are: impurity control in comtumporary tokamaks; surface pumping in shon pulse DTburing devices to minimize tritium inventor; and 
uall-conditioning of future large machines prior to cperation.

\section{References}

[1] P.E Stott. C.C. Daughney and R.A. Ellus. Nucl. Fus. 15 (1975) 431.

[2] A.: Wiootion. P.H. Edmonds. R.C. Isier and P.K. Mioduszewsil. J. Nucl. Mater. 11]-112 (1982) 479 .
[3] J.L. Cecchi and R.J. Kinze. J. Vac. Sor. Ser. II. 2 (1984) 1234.

[4] R.J. Tayior, R.F. Bunshah and F. Schwirke. J. Nucl. Mater. 93-94 (1980) 338.

[5] J.E. Simpkins. P.K. Mioduszewski and L.U: Stratton. J. Nucl. Matet. 111-112 (1982) 827.

16) J.E. Simpkuns. W.A. Gabbard. L.C. Emerson and P.K. Mioduszewski. J. Nucl. Maler.trober

$122 \& 123(1924) 1431$

\section{DISCLAIMER}

This report was prepared as an account of work sponsored by an agency of the United States Governinent. Neither the United States Government nor any agency thereof, nor any of their employees, makes any warranty, express or implied, or assumes any legal liability or responsibility for the accuracy, completeness, or usefulness of any information, apparatus, product, or process disclosed, or represents that its use would not infringe privately owned rights. Reference hereis to any specific commercial product, process, or seryice by trade name, trademark, manufacturer, or otherwise does not necessarily constitute or imply its endorsement, recommendation, or favoring by the United States Government or any agency thereof. The views and opinions of authors expressed her $\cdots$ do not necessarily state or reflect those of the United States Government or any agency thereof. 